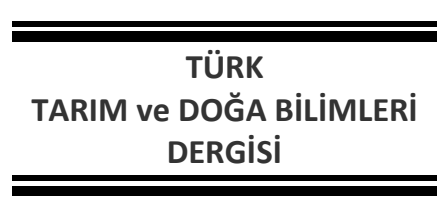

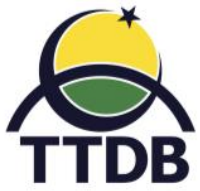

www.dergipark.gov.tr/turkjans

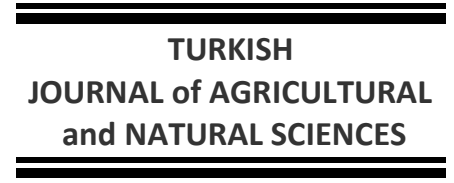

Araştırma Makalesi

\title{
DDVP (2,2- Diklorovin Dimetil Fosfat)'nin Gökkuşağı Alabalığında (Oncorhycnhus mykiss (Walbaum, 1972)) GH-I, IGF-I ve IGF-II Gen Ekspresyonları Üzerine Etkisi
}

\author{
Veysel PARLAK ${ }^{1 *}$, Orhan ERDOĞAN ${ }^{2}$ \\ ${ }^{1}$ Atatürk Üniversitesi, Su Ürünleri Fakültesi, Yetiştiricilik Bölümü \\ ${ }^{2}$ Atatürk Üniversitesi, Fen Fakültesi, Moleküler Biyoloji ve Genetik Bölümü \\ *Sorumlu yazar: veyselparlak@gmail.com
}

Geliş Tarihi: 07.03.2018

Düzeltme Geliş Tarihi: 25.05.2018

Kabul Tarihi: 28.05.2018

\section{Özet}

Çalışmamızda DDVP (2,2- Diklorovin Dimetil Fosfat)'nin Gökkuşağı Alabalıklarında büyüme ile ilgili olan; GH-I, IGF-I ve IGF-II gen ekspresyonları üzerine olan etkisi incelenmiştir. Çalışma süresince balıklar $1.6 \mathrm{mg} \mathrm{I}^{-1}$ DDVP'ye maruz bırakılmıştır. Kas dokusundan alınan örnekler üzerinde incelemeler yapılmıştır. Gen bölgelerine özgü primer ve Tagman probu kullanılarak Real-Time PCR yöntemi ile gen amplikasyonu gerçekleştirilmiş, gen ekspresyon seviyeleri belirlenerek istatiksel analizler yapılmıştır. Sonuç olarak, kas dokusunda yapılan incelemelerde; muamele grubunda IGF-I ve IGF-II aktivitesinde istatistiki önem derecesinde azalmalar belirlenmiştir. Ayrıca kontrol grubunda GH-I ve IGF-I seviyeleri pozitif iken IGF-II seviyesi negatif değerde çıkmış kimyasal uygulanan grupta ise GH seviyesinde artış IGF-I ve IGF-II seviyelerinde azalmalar belirlenmiştir. DDVP'nin alabalıklarda kas dokularında büyüme hormonu salınımını azalttığı söylenebilir.

Anahtar kelimeler: Gökkuşağı Alabalığı (Oncorhycnhus mykiss), DDVP (2,2- Diklorovin Dimetil Fosfat)'nin, GH-I, IGF-I, IGF-II, gen ekspresyonu.

\section{The Effects of DDVP on the GH-I, IGF-I AND IGF-II Genes Expression in Raınbow Trout (Oncorhycnhus mykiss (Walbaum, 1972)}

\begin{abstract}
In this study, the effects of DDVP (2,2-Dichlorovin Dimethyl Phosphate) on the GH-I, IGF-I and IGF-II expression gene in rainbow trout (Oncorhycnhus mykiss) were investigated. During the study, the fish were exposed to $1.6 \mathrm{mg} \mathrm{l}^{-1}$ DDVP. The study was conducted on the samples taken from muscle tissue. Gene amplification was actualized with Real Time method by using primer and Probe of Tagman which are specific to gene parts and statistical analyses were conducted through setting the level of gene expression. As a result, in the studies on the tissue of muscle, decreases in the statistical significance of were identified in the activities of IGF-I and IGF-II which were in the treatment group. Moreover, the level of GH-I and IGF-I was positive in the control group while the level of IGF-II was negative and an increase was observed in the level of GH and a decrease was observed in the levels of IGF-I and IGF-II in the group of which chemicals were applied. It is determined that DDVP decreases the secretion of growth hormone on the tissues of muscle in trout.
\end{abstract}

Key words: Rainbow trout (Oncorhycnhus mykiss), DDVP (2,2-Dichlorovinyl Dimethyl Phosphate), GH-I, IGF-I, IGFII, gene expression.

Giriş

Su, canlı ve cansız tüm organizmaların yaşamını sürdürebilmesi için vazgeçilmez bir yaşam kaynağıdır. Günümüzde su kaynaklarının maruz kaldığı en ön önemli sorun bilinçsiz kullanılması ve kirletilmesidir. Sanayi kaynaklı kirliliğin ve evsel atıkların artması sonucu kaynak sularımız daha fazla 
kirletilmektedir. Ekolojik dengenin bozulması canlı yaşamını da olumsuz olarak etkilemektedir. Zirai uygulamalarda ve barınma alanlarında zararlılara karşı mücadele için yoğun olarak kullanılan kimyasalların başında pestisitler gelmektedir. Bu kimyasallar, zararlı böcek, hayvan, bitki ve mikroorganizmaları ortamdan uzaklaştırmaya ya da üremelerini durdurma yönünde bir mekanizmaya sahiptirler. Pestisitlerin yoğun ve bilinçsiz olarak kullanılması sonucunda ekosistemde meydana gelen kirlilik besin zincirindeki tüm canlıları etkilemektedir. Ekosisteme karışan bu kirleticiler toprakta, suda, meyve ve sebzelerde birikmekte besin zinciri yoluyla insanlara kadar ulaşmaktadır. Yapılan birçok çalışmada pestisitlerin alerjik, karsinojenik, mutajenik ve teratojenik etkilerinin olduğu rapor edilmiştir (Durmuş, 2009, Parlak, 2018).

Pestisit grupları içerisinde Organofosfat grubu önemli yer tutmaktadır. Organik fosfatı (OP) bileşikler yapılarında bulunan fosfor atomlarından dolayı bu isimle adlandırılmaktadırlar. OP'ler tarım alanlarında ve halk sağığı uygulamalarında kullanılmaktadır. Bu kimyasalların canlıya geçişi; temas, sindirim ve solunum yoluyla olmaktadır. OP bileşikler geniş spektrumlu yapısı, doğada çabuk bozulma oranına sahip olması ayrıca memeli ve kuşlarda düşük toksik etkisinden dolayı yoğun olarak kullanılmaktadır. OP'lerin kimyasal yapıları fosforik ya da fosforik asit bağlı ester veya amidlerden meydana gelmiştir. Malathion, parathion, diklorvos, diazinon yoğun olarak kullanılan organofosfatlı insektisitlerdendir (Yavuz ve Şanlı, 1999; Çakır ve Yamanel, 2005).

DDVP zararlı böceklerin kontrolünde en fazla kullanılan insektisitlerin biridir. Toksik etkisi zamanla azalmasına rağmen ve hedef dışı türler üzerinde de olumsuz etkilere neden olmaktadır. Insektisitler türe spesifik olmadıkları için sadece hedef organizmaları etkilemez aynı zamanda diğer omurgalı ve omurgasız canlıları da olumsuz olarak etkiler. Pestisitin canlı üzerindeki etkileri, insektisitin ve formülasyonun tipine, uygulama şekline ve tarımsal arazinin tipine bağlı olarak farklılık göstermektedir (Yücel, 2007).

Kimyasal uygulaması sonucunda sucul ortamda meydana gelen kirlilikten elbette en çok suda yaşayan canlılar zarar görmektedir. Bu canlıların başında da balıklar gelmektedir. Sucul ortama karışan bu kirleticiler balıklar için gerekli olan besin zincirini bozmakta ve canlıların metabolizmasına karışarak, hayati faaliyetlerinde düzensizliklere sebep olabilmektedir. Kirleticiler balıkların gelişme ve üreme metabolizmalarını olumsuz olarak etkilemektedir. $\mathrm{Bu}$ etkiler kirleticilerin konsantrasyonlarına bağlı olarak balıklarda beslenme düzensizlikleri büyümenin durması, yumurta dökme veya testis ovaryum gelişiminin gerilemesi ve ölümle sonuçlanmaktadır (Oğuzhan ve Atamanalp, 2008).

Balıklarda büyüme; tüketilen besinin sindirimi ve bunun sonucunda vücutta meydana gelen boy ve ağırlık artışı olarak ifade edilir. Büyüme, cinsi olgunlukta daha hızlı olmak üzere ömrün sonuna kadar devam eder. Ayrıca büyüme türler arası ve türler içinde farklılık göstermektedir. Kalıtım, cinsi olgunluk ve ömür uzunluğu gibi iç faktörler yanında, su sıcaklığı, ortamdaki besin miktarı, besin göçü, mevsimsel değişimler, hastalıklar ve sucul ortamdaki kirlilik gibi dış faktörlerde balıklarda büyümeyi doğrudan veya dolaylı olarak etkilemektedir (Çetinkaya ve ark., 2005; Parlak, 2010).

Besin değeri ve ekonomik önemi açısından alabalıklar, besin zincirinde önemli bir yere sahiptir. Özelliklede iç sularımızda büyük bir yaşama payına sahip olan alabalıklar hem lezzeti hem de kolaylıkla kültüre alınıp yetiştirilebilmesi açısından önemlidir. Yetiştiriciliği yapılan balık türlerinin, en iyi şekilde üretilmesi ve en kısa zamanda sofralık boya gelmesinde önemli etkenler yer almaktadır ve bunların belirlenmesinde türlerin kalıtsal ve genetiksel özelliklerin belirlenmesi önem arz etmektedir. Mümkün olan en kısa sürede, daha fazla ve sağlıklı ürünler elde etmek içinde biyoteknoloji alanındaki uygulamalardan yararlanılmaktadır (Şahin, 2003).

Su ürünleri yetiştiriciliği alanında ise biyoteknoloji; yetiştiricilik alanında daha fazla ürün elde etmeye, organizmada cinsel olgunlaşma yaşını düşürerek üreme periyodunu hızlandırmaya, büyüme hızı, yumurta verimi ve larval safhadaki yaşama oranını artırmayı ve hastalıklara karşı direnç oluşturmayı amaçlamaktadır (Şahin, 2003).

Balıkların büyüme aktivitesiyle doğrudan ilişkili olan Büyüme hormonu $(\mathrm{GH})$ beyinde bulunan hipofiz bezinden salgılanır. Hipotalamustan salgılanan büyüme hormonu salgılatıcı hormon (GHRH), GH hormonunun artmasına ve somatostatin hormonunun azalmasına neden olur (Duan, 1998). Kan'a karışan büyüme hormonu karaciğere ulaşır ve burada IGF-I isimli hormonu salgılatır. IGF-I hormonun aşırı salgılanması büyüme hormonu salgısını önler. Karaciğerden başka böbrek, bağırsaklar ve kıkırdak dokusunda da IGF-I (Insülin benzeri büyüme hormonu) salınımı yapılmaktadır. IGF-ı hormonu kas, kıkırdak ve kemik büyümesinde görev almaktadır (Özata, 2010).

Peptid yapısında bir molekül olan $\mathrm{GH}$ hormonunun dokular üzerindeki etkisi insülin benzeri büyüme faktörleri (IGF-I-II) aracılığı ile gerçekleşmektedir. IGF'ler aminoasit dizisi olarak insüline benzeyen polipeptid yapılardır (Reinecke, 2010). IGF'ler spesifik bağlayıc proteinler (IGFBPs) 
ile etkileşime girerek biyolojik aktivitelerini gerçekleştirmektedirler. Memelilerde altı farklı IGF bağlayıcı plazma proteini tanımlanmıştır. Kan dokusundaki IGF-I'in \%75'inden fazlası glikolizlenmiş bağlayıcı protein olan IGFBP-3, ile kompleks oluşturur. Bağlayıcı proteinlerin konsantrasyonu GH'e bağlı olarak değişmektedir (Kelley ve ark., 1995). IGF'ler hücre kültüründe insülin ile benzer olan biyolojik görevleri almaktadırlar. IGF-I kıkırdak dokuda büyümeyi teşvik etmeye ek olarak diğer dokularda da insülin benzeri etki gösterir. Yağ yıkımını baskılayıp yağ dokusunda glikoz yıkımını arttırır. Ayrıca kalsiyum, magnezyum ve potasyum dengesine de olumlu etkileri olduğu rapor edilmiştir. IGF-I düzeyi hipotiroidizm, kronik hastalık, beslenme eksiklikleri ve karaciğer hastalıkları birçok olumsuz durumda azalma gösterir (Pérez-Sánchez ve ark., 2002). GH ve IGF'ler balıklarda hücre içi enge, lipid ve protein metabolizması, kıkırdak doku büyümesi, üreme ve immün sistem dahil olmak üzere birçok biyolojik faaliyette görev almaktadır (Gomez-Requeni ve ark., 2012). Tüm bu bilgiler göz önünde tutulduğunda GH-I, IGF-I ve IGF-II genlerinin büyümeyle direkt etkisi olduğu söylenebilir.

Memeli organizmalarda insülin benzeri büyüme faktörü-I (IGF-I)'nın ana görevi lipid ve protein sentezi ile hücre bölünmesini uyarmak olan salınımı uyarmaktır. Balıklarda beslenme sonucunda büyüme faktörlerinin salımı artış göstermektedir. Birçok kemikli balıkta, beslenme oranı ve sıklığı ile IGF-ı ve GH arasında korelasyon açıktır (Davie, 2005). Karaciğer, böbrek ve bağırsak gibi birçok doku tarafından sentezlenebilen İnsülin benzeri büyüme faktörleri (IGF) somatik büyümede rol almaktadır. IGF-I ve IGF-II olarak iki önemli forma sahiptir. IGF-I genel olarak larval dönem sonrası büyümede görev alırken IGF-II ise embriyolojik dönemdeki büyüme üzerinde etkilidir. IGF'nin kas dokusunda etkisi hareket ile artış göstermektedir. Ayrıca besin alımı IGF-I'in serum seviyelerindeki değişimini etkileyen en önemli faktördür. IGF-I'in serum seviyelerinde değişimi stabil ve uzun sürelidir. IGF-I'in besin alımındaki etkiye hassasiyeti IGF-II'ye göre daha fazladır. Son yıllarda yapılan çalışmalarda IGF-I'in GH'dan bağımsız şekilde mekanik yüke duyarlı olan satellit hücre aktivasyonunu artırdığı, böylece kas hipertrofisine neden olduğu rapor edilmiştir (Harbili, 2008).

DDVP'nin gökkuşağı alabalığının kas dokusundaki 3 önemli gene (GH-I, IGF-I ve IGF-II) olan etkisi ile ilgili geniş kapsamlı ve kombine bir çalışmaya literatürlerde rastlanmamıştır Kimyasal uygulamasI sonucunda bu IGF-I, IGF-II ve GH-I genlerin ekspresyon seviyelerinde meydana gelen değişikleri belirlemek için moleküller düzeyde incelemeler yapılmıştır.

\section{Materyal ve Yöntem}

Çalışma Atatürk Üniversitesi Su Ürünleri Fakültesi Akvaryum Balıkları Uygulama ve Araştırma Merkezinde bulunan Toksikoloji Deneme Ünitesi'nde ve Su Ürünleri Fakültesi Laboratuvarlarında gerçekleştirilmiştir.

\section{Balık materyali ve uygulama alanı}

Balıklar, Atatürk Üniversitesi iç Su Balıkları Araştırma ve Uygulama Merkezinden temin edilmiştir. Denemede $150 \pm 20$ gr ağırlığında 20 adet sağlıklı gökkuşağı alabalığı (O. mykiss) kullanımıştır. Uygulama 650 litrelik fiberglas tanklarda biri kontrol diğeri muamele grubu olarak yapılmıştır (Esenbuğa, 2013). Denemeye alınan balıklar 14 gün aklimasyona tabi tutulmuş ve $\% 45$ proteinli ticari (Sibal A.Ş.) yemle, günlük olarak canlı ağırlığın \%2'si oranında günde iki kere sabah-akşam yemleme yapılmıştır. Tanklar günde iki kere tahliye borusu yardımıyla sifonlanarak yem ve dışkı artıklarının ortamdan uzaklaştırılması sağlanmıştır.

\section{Denemede kullanılan kimyasal ve uygulaması}

Pestisit olarak kullanılan Diklorvos (DDVP) ticari bir firmadan (Sigma, $\geq 98 \%$ (HPLC) temin edilip EPA (2006)'ya göre LC $_{50}$ seviyesinin altındaki dozlar 12 saatte bir yenilenebilir statik test yöntemi (Bricknell ve ark., 1999) dikkate alınarak belirlenmiştir. Balıklar 21 günlük uygulamada pestisitin $1.6 \mathrm{mg} / \mathrm{l}$ subletal konsantrasyonuna maruz bırakılmıştır. Tanklara "ortamı yenilenen deneyler" prosedürüne göre 12 saatte bir konsantrasyonlar verilmiştir (Esenbuğa 2013, Parlak ve Atamanalp 2017 ). 0 ve 21. günlerde örnekleme yapılmıştır. Aklimasyon ve araştırma süresince kullanılan suyun kimyasal özellikleri Oksijen $\left(\mathrm{O}_{2}\right)$ : 8.8 ppm, Nitrat $\left(\mathrm{NO}_{3}{ }^{-}\right): 3.45 \mathrm{mg} / \mathrm{L}$, Amonyak $\left(\mathrm{NH}_{3}\right): 3.45$ $\mathrm{mg} / \mathrm{L}, \quad \mathrm{pH}: \quad 7.9$ ve Sıcaklık: $9.6 \pm 1^{\circ} \mathrm{C}$ olarak ölçülmüştür.

\section{RNA izolasyonu}

Uygulama sonrasında kas dokusu örnekleri alınıp TRIzol ${ }^{\circledR}$ Reagent solüsyonu içerisinde soğuk şartlarda ultraturaks yardımıyla parçalanmıştır. Total RNA'nın izolasyonu, ilgili solüsyon protokolünde belirtilen yöntem kullanılarak gerçekleştirilmiştir. Total RNA konsantrasyonları ve varlığı, spektrofotometrik ölçümler ve elektroforez uygulamasıyla belirlenmiştir. Total RNA'nın kalitatif tayininde RNA varlığının kontrolü için agaroz jel elektroforezi uygulanmıştır. RNA örneği üzerine $\mathrm{ddH}_{2} \mathrm{O}$ eklenerek hacim 4,5 $\mu \mathrm{l} / \mathrm{L}(1 \mu \mathrm{l}$ RNA $+3,5 \mu \mathrm{l}$ $\mathrm{ddH}_{2} \mathrm{O}$ ) ye getirilmiştir. Üzerine $0,5 \mu \mathrm{l}$ 20xMOPS (3(N-morfolino) propansülfonik asit) solüsyonu ve sonrasında $5 \mu \mathrm{l}$ formamid eklenerek $65^{\circ} \mathrm{C}^{\prime} \mathrm{de} 15 \mathrm{dk}$ inkübasyona bırakılmıştır. Daha sonrasında 
hazırlanan RNA örnekleri jelde yürütülmüştür. İzole edilen RNA'ların yoğunlukları spektrofotometre ile 2 tekerrürlü olarak ölçülmüştür. Bu elde edilen değerlerin ortalaması alınarak seyrelme faktörü ile çarpılmış ve RNA yoğunluğu hesaplanmıştır. RNA dilüsyonu $1 / 50$ olacak şekilde hazırlanarak örnekler 260 ve $280 \mathrm{~nm}$ dalga boyunda spektrofotometrik olarak ölçülüp, absorbans değerleri saptandıktan sonra yoğunluk değeri hesaplanmıştır. Total RNA'nın konsatrasyonu $(\mu \mathrm{g} / \mu \mathrm{l})=260 \mathrm{~nm}$ 'deki absorbans değeri x seyreltme faktörü (1000) x40 (Ekstriksiyon

katsayısı) (http://www.pubquizhelp.34sp.com/other/dnacalc ulator.html). RNA'nın yapısında yer alarak hücrelerdeki genetik bilginin kodlanmasında önemli bir rol oynayan pürin ve pürimidin bazları 260-280 dalga boyunda absorbans verdiği için bu dalga boylarında ölçüm yapılmıştır. Sonraki aşamada Total
RNA'lardan reverse transkriptaz enzimi ile cDNA kütüphanesi oluşturulmuş ve örnekler çalışılıncaya kadar $-20^{\circ} \mathrm{C}^{\prime}$ de saklanmıştır (Erdoğan ve ark., 2008). Gen ekspresyon ölçümü için İnternet ortamındaki gen bankasından (http://www.ncbi.nlm.nih.gov/) gökkuşağı alabalığında GH-I, IGF-I ve IGF-II genlerine ait mRNA baz dizilimleri kullanılarak internet ortamındaki başka bir primer dizayn programında (http://frodo.wi.mit.edu/cgibin/

primer3/primer3_www.cgi/) genlerin maksimum 250 bp'lik kısmına spesifik primerler ve problar oluşturulmuştur (Çizelge 1). Son olarak hazırlanan örnekler Real-Time PCR uygulaması ile değerlendirilmiştir. Amplifikasyon oranının hesaplanması. IGF-II değerine ait standart eğri, $X$ ve $Y$ ekseninde sırasıyla cDNA seyreltme faktörünün ve Ct değerlerinin logaritmik bölgesi Şekil 1'de gösterilmiştir.

Çizelge 1. Genlere spesifik primer dizaynları.

\begin{tabular}{|c|c|c|c|}
\hline Genler & Primer dizilimi $\left(5^{\prime} \rightarrow 3^{\prime}\right)$ & Çoğaltılacak & Gen bankası \\
\hline GH-I Forward & AATGGTCAGAAATGCCAACC & & \\
\hline GH-I Reverse & AAGCAAGCCAACAACTCGTAG & $201 \mathrm{bp}$ & NM_001124689,1 \\
\hline GH-I Prob & FAM - CATCAACCTGCTCATCACGGGG -TAMRA & & \\
\hline IGF-I Forward & ATGTGCTGTGTCTCCTGTACCC & & \\
\hline IGF-I Reverse & TAAAAGCCTCTCTCTCCACACA & 149 bp & M95183.1 \\
\hline IGF-I Prob & FAM_ TAACCCTGACTTCGGCGGCA - TAMRA & & \\
\hline IGF-II forward & GAAGGTCAAGATGATGTCTTCG & & \\
\hline IGF-II Reverse & AGTTCTCCTCCACATAGCGTTT & $108 \mathrm{bp}$ & M95184.1 \\
\hline IGF-II Prob & FAM_ TCGAGTGCTGGTCATTGCGC-TAMRA & & \\
\hline GAPDH forward & ATCAAAGGGGCTGTCAAGAA & & \\
\hline GAPDH Reverse & AGGAGTGGGTGTCTCCAATG & $106 \mathrm{bp}$ & NM_001124246 \\
\hline GAPDH TaqMan Prob & Cy5- CGCCGAAGGACCCATGAAGG - ${ }^{\mathrm{BQ} 2}$ & & \\
\hline
\end{tabular}

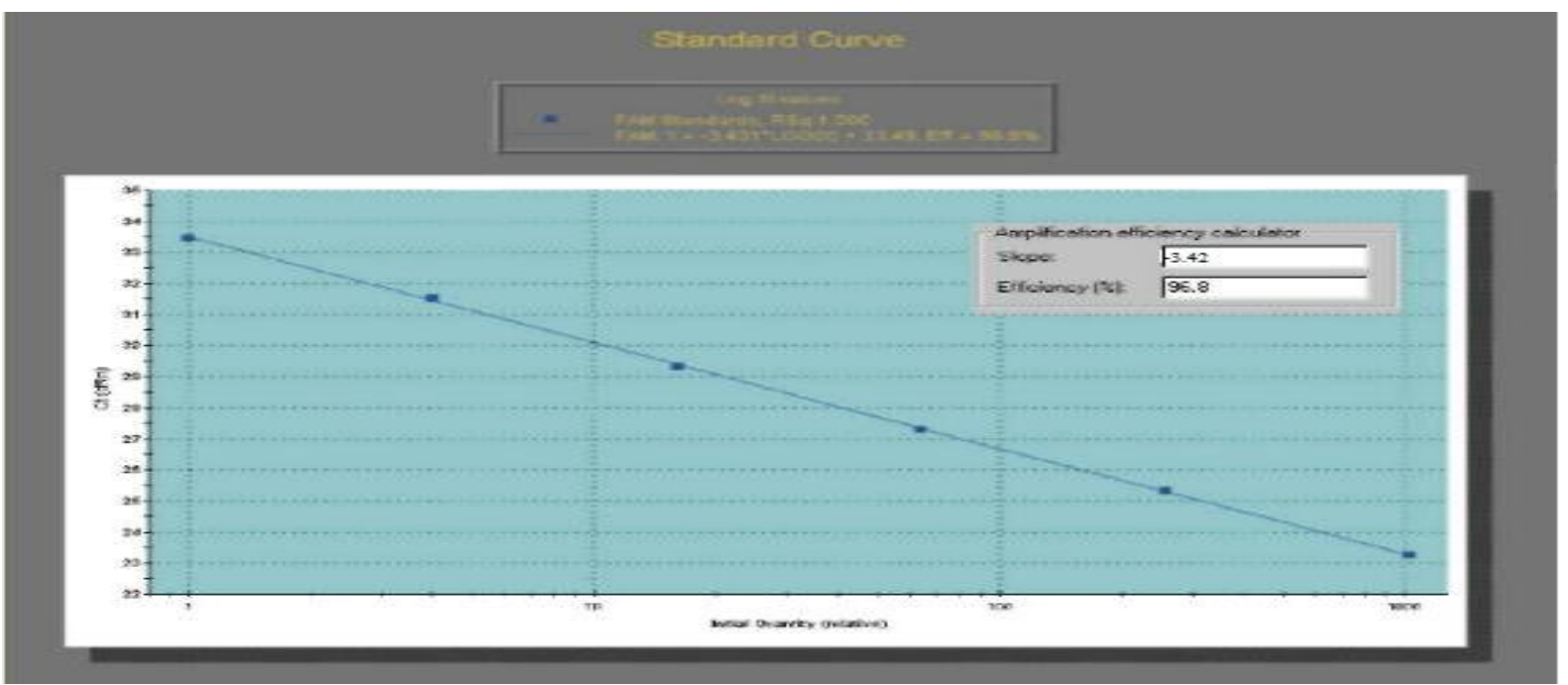

Şekil 1. Amplifikasyon oranının hesaplanması. IGF-II değerine ait standart eğri, $X$ ve $Y$ ekseninde sırasıyla cDNA seyreltme faktörünün ve $\mathrm{Ct}$ değerlerinin logaritmik bölgesi. 


\section{Istatistiki analiz}

Elde edilen sonuçların istatistiki analizi için Statistica $6.0 \quad$ (StatSoft $^{\circledR} \quad$ Inc., USA) programı kullanılmıştır.

\section{Bulgular ve Tartışma}

\section{RNA izolasyonuna ve PCR analizine ilişkin bulgular}

Kas dokusundan TRIzol ${ }^{\circledR}$ Reagent yöntemi ile izole edilen total RNA'ların varlığının kontrolü için \%1'lik agaroz jel elektroforezi yapılarak Şekil 2'deki bant görüntüsü elde edilmiştir. Amplifikasyon etkinlik oranı, $e=10^{(-1 / \text { slope })}$ formülü ve slope değeri (stratagen MxPro3000 Software programı ile) kullanılarak hesaplanmıştır. Çizelge 2'de primerlere ait etkinlik oranları verilmiştir. Amplifikasyon etkinlik oranı 2 olursa dizayn edilen primerin gene spesifikliği \%100 demektir. Bu değer azaldıkça spesifiklikte azalır. Kas dokusunda GH-I, IGF-I ve IGFII seviyelerindeki değişiklik, kimyasal ve kontrol grubuna göre $p<0,01$ istatistikî önem derecesine göre kıyaslanarak belirlenmiştir. Genlere ait kontrol ve muamele grupları arasındaki $\Delta \mathrm{Ct}$ değerleri Çizelge 3'te verilmiştir.
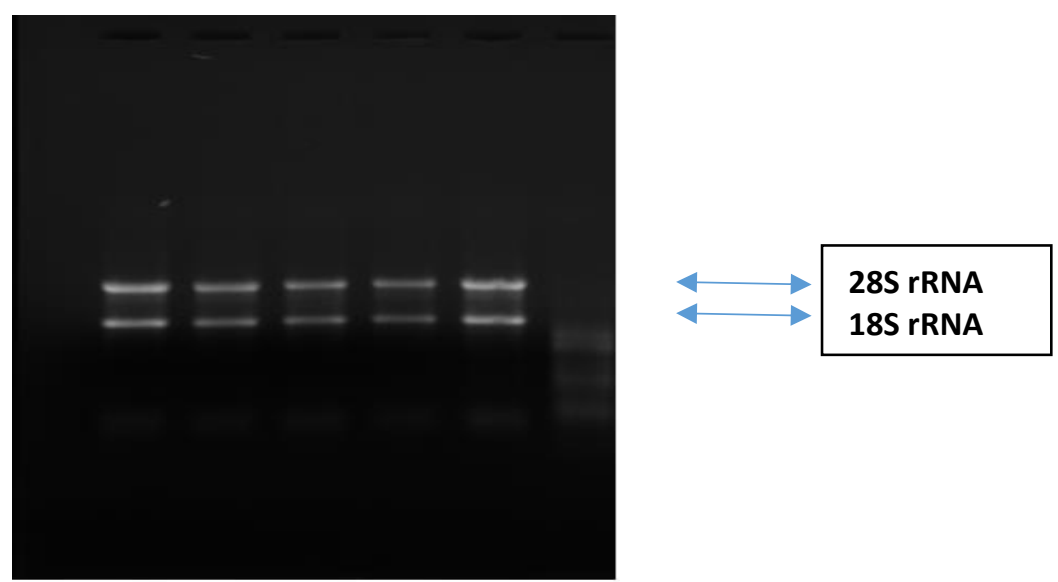

Şekil 2. RNA'nın Agaroz Jel Elektroforezinde Kontrolü. Soldan sağa doğru 1. Kuyu kontrol, 2, 3, 4 ve 5 . kuyular kimyasal uygulanan balıklara aittir.

Çizelge 2. Real-time PCR'da kullanılan primerlere ait etkinlik oranları.

\begin{tabular}{lcc}
\hline Genler & Slope değeri & Primer Etkinlik Oranı \\
\hline GH-I & $-3,54$ & 1.93 \\
IGF-I & $-3,58$ & 1.91 \\
IGF-II & $-3,42$ & 1.96 \\
GAPDH & $-3,61$ & 1.90 \\
\hline
\end{tabular}

Çizelge 3. Genlere ait kontrol ve muamele grupları arasındaki $\Delta \mathrm{Ct}$ değerleri.

\begin{tabular}{|c|c|c|c|c|}
\hline Genler & Muamele & Ortalama $\Delta \mathrm{Ct}^{\mathrm{x}}$ & $\Delta \Delta \mathrm{Ct}^{\mathrm{y}}$ & Fold Azalışı $\left(2^{\Delta \Delta \mathrm{Ct}}\right)$ \\
\hline \multirow{2}{*}{ GH-I } & Kontrol & $1,80 \pm 0,07^{b}$ & \multirow{2}{*}{3,27} & \multirow{2}{*}{0,14} \\
\hline & DDVP $1,6 \mathrm{mg} / \mathrm{L}$ & $5,07 \pm 0,27^{a}$ & & \\
\hline \multirow{2}{*}{ IGF-I } & Kontrol & $0,78 \pm 0,17^{b}$ & \multirow{2}{*}{$-4,85$} & \multirow{2}{*}{21,92} \\
\hline & DDVP $1,6 \mathrm{mg} / \mathrm{L}$ & $-4,07 \pm 0,05^{a}$ & & \\
\hline \multirow{2}{*}{ IGF-II } & Kontrol & $-3,07 \pm 0,07^{b}$ & \multirow{2}{*}{$-0,57$} & \multirow{2}{*}{1,48} \\
\hline & DDVP $1,6 \mathrm{mg} / \mathrm{L}$ & $-3,64 \pm 0,08^{a}$ & & \\
\hline
\end{tabular}

$\mathbf{a}, \mathbf{b}=\mathrm{Bu}$ değerler her bir genin kendi içerisindeki muamele ve kontrol değerleri dikkate alınarak $p<0.01$ seviyesindeki istatistiki önem derecesidir.

$\mathbf{x}=$ Kullanılan her balık için ilk önce $\Delta$ Ct değeri: aynı balığın GAPDH geninin -Ct seviyesi ve DDVP -Ct seviyeleri bulunarak hesaplandı. Daha sonra ortalama $\Delta C t$ değeri uygulamaya tabi tutulan her bir balık için $\mathrm{Ct}$ değeri bulunarak hesaplandı.

$\mathbf{y}=\Delta \Delta \mathrm{Ct}$ değeri, kimyasal uygulanan grubun değerinin ortalaması ile kontrol grubunun ortalama $\Delta \mathrm{Ct}$ değerinin karşılaştırılmasıyla hesaplandı. 


\section{Istatistiki analiz sonuçları}

Real-Time PCR uygulaması sonucunda elde edilen verilerin Statistica 6.0 programıla değerlendirilmesi sonunda aşağıdaki verilere ulaşılmıştır.

\section{GH-I}

Kontrol $\Delta c_{t}=$ Kontrol GH-I $\Delta \mathrm{Ct}-$ Kontrol GAPDH $\Delta \mathrm{Ct}$ $D_{D V P} \mathrm{CCt}=$ DDVP uygulanmış balık GH-ı $\Delta \mathrm{Ct}$ - DDVP uygulanmış balık GAPDH $\triangle \mathrm{Ct}$

$\Delta \Delta \mathrm{Ct}=\mathrm{DDVP}_{\Delta \mathrm{Ct}}-$ Kontrol $_{\Delta \mathrm{Ct}} \quad E^{-\Delta \Delta \mathrm{Ct}}=1,93^{-\Delta \Delta \mathrm{Ct}}$

\section{IGF-I}

Kontrol $_{\Delta \mathrm{Ct}}=$ Kontrol IGF-I $\Delta \mathrm{Ct}-$ Kontrol GAPDH $\Delta \mathrm{Ct}$ $D_{D V P} \Delta \mathrm{Ct}=$ DDVP uygulanmış balık IGF -I $\Delta \mathrm{Ct}$-DDVP uygulanmış balık GAPDH $\triangle \mathrm{Ct}$

$\Delta \Delta C \mathrm{C}=\mathrm{DDVP}_{\Delta \mathrm{Ct}}-$ Kontrol $_{\Delta \mathrm{Ct}} \quad E^{-\Delta \Delta \mathrm{Ct}}=1,91^{-\Delta \Delta \mathrm{Ct}}$

\section{IGF-II}

Kontrol $_{\Delta \mathrm{Ct}}=$ Kontrol IGF-II $\Delta \mathrm{Ct}-$ Kontrol GAPDH $\Delta \mathrm{Ct}$ $D_{D V P} \mathrm{C}_{\mathrm{t}}=\mathrm{DDVP}$ uygulanmış balık IGF -II $\Delta \mathrm{Ct}$-DDVP uygulanmış balık GAPDH $\triangle \mathrm{Ct}$

$\Delta \Delta \mathrm{Ct}=\mathrm{DDVP}_{\Delta \mathrm{Ct}}-\mathrm{Kontrol}_{\Delta \mathrm{Ct}} \quad E^{-\Delta \Delta \mathrm{Ct}}=1,96^{-\Delta \Delta \mathrm{Ct}}$

Önceki çalışmalarda DDVP'nin enzimler, kan parametreleri, sub-letal doz belirleme, mortalite ve lokal dokularda meydana getirdiği değişiklikler incelenmiştir (Giordano ve ark., 1989; Levesque ve ark., 2002). Bu açıdan yapılan çalışma moleküler düzeyde DDVP'nin büyüme genlerinde meydana getirdiği değişikliklerin belirlenmesi açısından ilk ve önemlidir. Yapılan birçok çalışmada varılan ortak sonuç kirleticilerin gen ekspresyon seviyelerinde değişiklikler meydana getirdiğidir (Handy, 2003; Xiao-dong ve ark., 2007; Vergani ve ark., 2009).

Diğer çalışmalarda ise GH-I, IGF-I ve IGFII'nin büyüme üzerine olan etkileri incelenmiş yâda yapılan kimyasal uygulamalarının lipit ve protein metabolizması, asetilkolinesteraz aktivitesi, çeşitli plazma parametreleri, HSP-70 gen ekspresyonu değişimi, sebep olduğu mutasyon etkileri ve protein sentezi ile aminoasit emilimi gibi parametrelerde meydana getirdiği değişiklikler incelenmiştir (Kajimura ve ark., 2001; Pierce ve ark., 2004). Genel olarak DDVP ve benzeri pestisit uygulamalarının büyüme ve biyolojik aktivite üzerinde olumsuz etkiler meydana getirdiğini söyleyebiliriz. Ayrıca zirai uygulamalarda zararlı böceklere karşı uygulanan pestisitlerin diğer canlılarda yaratacağı öldürücü dozların belirlenmesi için bu ve benzeri çalışmalar önem teşkil etmektedir.

Yaptığımız çalışmada DDVP'ye maruz bırakılan gökkuşağı alabalıklarının büyüme genlerinde (GH-I, IGF-I, IGF-II) meydana gelen değişiklikler incelenmiştir. DDVP uygulaması sonrasında balıkların yem alımında azalmalar, yüzme hareketlerinde düzensizlikler ve durgunluk görülmüştür. 21 gün sonunda balıklardan alınan kas dokuları üzerinde yapılan incelemelerde büyüme gen ekspresyon seviyelerinde, kontrol grubu ve kimyasal uygulanan grup kıyaslandığında değişimler meydana geldiği gözlemlenmiştir.

Real-Time PCR uygulaması sonrasında genlere ait kontrol ve muamele grupları arasındaki $\Delta \mathrm{Ct}$ değerleri karşılaştırıldığında; $\mathrm{GH}-\mathrm{I}$ gen ekspresyon seviyesi büyümeye ve yaşa bağlı olarak artmakta iken kimyasal uygulamasına tepki olarak kontrol grubuna oranla daha fazla artış göstermiştir. $\mathrm{Bu}$ değer kontrol gurubunda $1,80 \pm 0,07^{\mathrm{b}}$ iken kimyasal uygulanan grupta $5,07 \pm 0,27^{\text {a }}$ olarak belirlenmiştir. IGF-I ve IGF-II gen ekspresyon seviyesi gen sırasıyla kontrol grubunda $0,78 \pm 0,17^{\mathrm{b}}$ ve $-3,07 \pm 0,07^{\mathrm{b}}$ kimyasal uygulaması yapılan grupta $4,07 \pm 0,05^{\text {a }}$ ve $-3,64 \pm 0,08^{a}$ olarak belirlenmiştir. Kimyasal uygulamasının kas dokusunda ki IGF-I ve IGF-II gen ekspresyon seviyelerinde azalmaya sebep olduğunu söyleyebiliriz. Bunun sonucunda DDVP'nin balıkların büyüme aktivitelerinde yavaşlamaya ve olumsuz biyolojik etkilere sebep olduğunu söylenebilir.

Çalışmada GH seviyesinde hem kontrol hem de muamele grubunda pozitif artış, IGF-I ve IGF-II seviyelerinde ise azalmalar belirlendiğini söyleyebiliriz. GH seviyesindeki artışın sebebini uygulanan kimyasala karşı karaciğer ve hipofiz tarafından bir direnç göstergesi olarak ifade edebiliriz. Ayrıca kimyasal uygulamasıyla balıklarda yem alım seviyesi düştüğü gözlemlenmiştir. Buna istinaden açlıktan dolayı GH salınımı arttığını ifade edebiliriz. GH, IGF-I ve IGF-II arasında meydana gelen farklılıkların sebebi olarak bu faktörlerin birbirleriyle ilişki içerisinde olmasının yanı sıra farklı işlev ve zamanlarda görev almasından kaynaklı olduğunu da söylenebilir.

\section{Sonuç ve Öneriler}

Sonuç olarak DDVP'nin alabalıkların büyüme genleri (IGF-I ve IGF-II) üzerinde olumsuz etkileri olduğunu ifade edebiliriz. Sucul ortamın bu ve benzeri kirleticilerden arındırılması kesinlikle bu ortamda yaşayan canlılar, özelliklede balıklar için önem arz etmektedir. DDVP benzeri pestisitlerin kullanımının kontrol altında tutulması ve daha dikkatli bir şekilde kullanılarak sucul ortama karışımının engellenmesiyle bu ortamda yaşayan balıkların bundan zarar görmesi önlenmelidir. Daha temiz su şartları sağlanarak balıkların büyüme ve gelişme evrelerinde mutlak gelişmeler gözlenebilecektir.

\section{Kaynaklar}

Bricknell, I.R., Bowden, T.J., Bruno, D.W., MacLachlan, P., Johnstone, R., Ellis, A.E. 1999. Susceptibility of Atlantic halibut, 
Hippoglossus hippoglossus (L) to infection with typical and a typical Aeromonas salmonicida. Aquaculture, 175: 1-13.

Çetinkaya, O., Sen, F., Elp, M. 2005. Balıklarda büyüme ve büyüme analizleri. Balık biyolojisi araştırma yöntemleri. Nobel yayınları, 498: 93-121.

Davie, A. 2005. Effect of Photoperiod Manipulation on Growth and Reproduction in Atlantic Cod (Gadus morhua L.). Ph.D. Thesis. Inst. of Aquaculture, Unv. of Stirling, Scotland.

Duan, C. 1998. Nutritional and Developmental Roles of Insulin-like Growth Factors between Species. Department of Biology, University of Michigan, Ann Arbor, MI 48109-1048.

Durmuş, D. 2009. DDVP'nin (Dichlorvos) Subletal Dozlarının Galleria mellonella L.'nın Protein, Lipit ve Karbonhidrat Düzeyine Etkileri. Yüksek Lisans Tezi, Çukurova Üniversitesi Fen Bilimleri Enstitüsü, Adana, Türkiye.

EPA, 2006. Registration Eligibility Decision for Dichlorvos (DDVP). United States Environmental Protection Agency, Washington D.C., 20460.2006. www.epa.gov/pesticides/reregistration/RED s/ddvp_i red.pdf.

Erdoğan, O., Küfrevioğlu, Ö.i.., Çankaya, M. 2008. Balık dokusundan RNA saflaştırılması. Su ürünlerinde uygulamalı moleküler biyoloji teknikleri. Atatürk Üniversitesi Ziraat Fakültesi Ders Yayınları. Erzurum, Türkiye. No: 237: 90-93.

Esenbuğa, H. 2013. Sds (Sodium dodecyl sulphate)'nin farklı dozlarının gökkuşağı alabalığının (O. mykiss) yüzme performansı, hematoloji parametreleri ve bazı antioksidan enzim aktiviteleri üzerine etkileri. Yüksek lisans Tezi, Fen Bilimleri Enstitüsü, Erzurum.

Giordano, R., Arata, P., Rinaldi. S., Ciaralli. L., Giani. M., Rubbiani. M., Costantini, S. 1989. Mercury, cadmium and lead levels in marine organisms (Mytilus galloprovincialis) collected along the Italian coasts. Ann. Ist. Super. Sanita, 25(3): 511-516.

Gomez-Requeni, P., Kramer, M.N., Canosa, L.F. 2012. Regulation of somatic growth and gene expression of the GH-IGF system and PRP-PACAP by dietary lipid level in early juveniles of a teleost fish, the pejerrey (Odontesthes bonariensis). Journal of comperative Physiology B, 182: 517-530.

Handy, R.D. 2003. Chronic effects of copper exposure versus endocrine toxicity: two sides of the same toxicological process. Comparative Biochemistry and Physiology Part A 135: 25-38.
Harbili, S. 2008. Insülin benzeri büyüme faktörleri (IGF): Egzersiz metabolizması ve kas dokusu üzerine etkileri. Genel Tıp Dergisi, 18(4): 177184.

Kajimura, S., Uchida, K., Yada, T., Riley, L.G., Byatt, J.C., Collier, R.J., Aida, K., Hirano, T., Grau, E.G. 2001. Effects of insulin-like growth factors (IGF-I and -II) on growth hormone and prolactin release and gene expression in euryhaline tilapia, Oreochromis mossambicus. General and Comparative Endocrinology, 127(3): 223-231.

Kelley, K.M., Oh, Y., Gargosky, S.E., Gucev, Z., Matsumoto, T., Hwa, V., Ng, L., Simpson, D.M. Rosenfeld, R.G. 1995. Int. J. Biochem. Cell. Biol. 28: 619-637.

Levesque, H.M., Moon, T.W., Campbell, P.C.G., Hontela, A. 2002. Seasonal variation in carbohydrate and lipid metabolism of yellow perch (Perca flavescens) chronically exposed to metals in the field. Aquatic Toxicology, 60(3-4): 257-267.

Oğuzhan, P., Atamanalp, M. 2008. Su kirliliğinin balıklarda üreme üzerine etkileri. Erzincan Üniversitesi AquaClub Su Ürünleri Araştırma ve Geliştirme Bilim Kulübü, Kemaliye 5.Geleneksel Su Ürünleri Bilimsel ve Kültürel Platformu.

Özata, M. 2010. Büyüme hormonu nedir. www.tavsiyeediyorum.com/makale_2899.h tm (04.20.2010).

Parlak, V. 2010. Ddvp (2,2- diklorovin dimetil fosfat)'nin Gökkuşağı alabalığında (Oncorhycnhus mykiss (walbaum,1972)) GHI, IGF-I ve IGF-II gen ekspresyonlari üzerine etkisi. Yüksek Lisans Tezi, Fen Bilimleri Enstitüsü, Erzurum.

Parlak, V., Atamanalp, M. 2017. Investigation of chronic effects of alfa-cypermethrın on haemototoxic parameters in the rainbow trout (Oncorhynchus mykiss). Aquaculture Studies.2017, Vol 17, Num, 3 (Pages: 259272).

Parlak, V. 2018. Evaluation of apoptosis, oxidative stress responses, AChE activity and body malformations in zebrafish (Danio rerio) embryos exposed to deltamethrin. Volume 207, September 2018, Pages 397-403. Chemosphere.

Pérez-Sánchez, J., Calduch-Giner, J.A., Mingarro, M., Vega-Rubín de Celis, S., Gómez-Requeni, P., Saera-Vila, A., Astola, A., Valdivia, M.M. 2002. Overview of Wsh growth hormone family. New insights in genomic organization and heterogeneity of growth hormone receptors. Fish Physiol. Biochem. 27: 243258. 
Pierce, A.L., Dickey, J.T., Larsen, D.A., Fukada, H., Swanson, P., Dickhoff, W.W. 2004. A quantitative real-time RT-PCR assay for salmon IGF-I mRNA, and its application in the study of $\mathrm{GH}-\mathrm{I}$ regulation of IGF-I gene expression in primary culture of salmon hepatocytes. General and Comparative Endocrinology, 135(3): 401-411.

Reinecke, M. 2010. Influences of the environment on the endocrine and paracrine fish growth hormone-insulin-like growth factor-I system. Journal of Fish Biology, 76: 12331254.

Şahin, T. 2003. Su Ürünleri Yetiştiriciliğinde Biyoteknoloji. Sümae Yunus Araştırma Bülteni, 3: 12-14.

Vergani, L., Lanza, C., Scarabelli, L., Canesi, L., Gallo, G. 2009. Heavy metal and growth hormone pathways in metallothionein regulation in fish RTH-149 cell line. Comparative Biochemistry and Physiology, Part C 149: 572-580.

Xiao-dong, J., Gui-zhong, W., Shao-jing, L., Jian-feng, H. 2007. Heavy metal exposure reduces hatching success of Acartia pacifica resting eggs in the sediment. Journal of Environmental Sciences 19: 733-737.

Yavuz, O., Şanlı, Y. 1999. Halk Sağlığı ve Vektör Kontrolünde Kullanılan Pestisidler, Pestisid Formülasyonları ve Uygulama Seçenekleri, I. Seminer. Ankara Üniversitesi Sağlık Bilimleri Enstitüsü, Farmakoloji Anabilim Dalı, Ankara.

Yücel, Ü. 2007. Pestisitlerin insan ve çevre üzerine etkileri. Nükleer araştırma ve eğitim merkezi, nükleer kimya bölümü, Ankara, www.dogainsanisbirligidernegi.org.tr/makal eler/pestisitler.doc, (Erişim tarihi: 15.05.2010). 